\title{
PERBANDINGAN METODE ANP DAN AHP DALAM PEMILIHAN JASA KURIR LOGISTIK OLEH PENJUAL GADGET ONLINE
}

\author{
Albert Julius Olanta, Martinus Edy Sianto*, Ivan Gunawan \\ Jurusan Teknik Industri, Fakultas Teknik, Universitas Katolik Widya Mandala Surabaya, Jalan Kalijudan \\ 37 Surabaya \\ Email: martinus.sianto@gmail.com
}

\begin{abstract}
ABSTRAK
Gaya hidup masyarakat utamanya di kota-kota besar dengan rutinitas pekerjaan yang banyak menyita waktu dan tenaga menyebabkan sebagian orang lebih suka berbelanja secara online. Keuntungan utama dari berbelanja online adalah harga barang yang cenderung lebih murah karena pedagang dapat menekan biaya operasional serta harga dapat dikomparasikan dengan cepat oleh pembeli. Selain itu, jarak tidak lagi menjadi hambatan dalam berbelanja. Pada setiap transaksi barang secara online membutuhkan dukungan dari jasa kurir logistik untuk mengirimkan. Perusahaan jasa kurir logistik besar yang mampu menangani pengiriman antar kota dan antar provinsi diantaranya adalah Tiki, JNE, J\&T, dan PT. Pos Indonesia. Untuk menangani barang yang mahal dan cukup rentan perlu banyak kriteria dan ketelitian didalam memilih jasa logistik.Penelitian ini bertujuan untuk mengidentifikasikan faktor-faktor yang mempengaruhi pelanggan dalam memilih jasa kurir. Dengan metode ANP dan AHP dapat diketahui bahwa jasa kurir yang terbaik untuk pengiriman gadget di kota Surabaya adalah ekspedisi JNE dengan faktor yang paling berpengaruh diurutkan mulai dari yang terpenting adalah Ketepatan Waktu, Keamanan Pengiriman, dan Jaminan Ganti Rugi.
\end{abstract}

Kata Kunci: Analytic Network Process, Analytical Hierarchial Process, Jasa Pengiriman

\section{Pendahuluan}

\section{I.1. Latar Belakang}

Di era digital ini, terjadi pertumbuhan pesat pada aktivitas belanja secara online. Gaya hidup masyarakat utamanya di kota-kota besar dengan rutinitas pekerjaan yang banyak menyita waktu dan tenaga menyebabkan sebagian orang lebih suka berbelanja secara online. Keuntungan utama dari berbelanja online adalah harga barang yang cenderung lebih murah karena pedagang dapat menekan biaya operasional serta harga dapat dikomparasikan dengan cepat oleh pembeli. Selain itu, jarak tidak lagi menjadi hambatan dalam berbelanja. Para pelaku bisnis online masuk ke pasar dengan mudah, murah, dan tanpa batasan geografis. Pembeli dapat dengan mudah memilih bertransaksi dengan pedagang yang berada di berbagai lokasi di seluruh dunia. Selanjutnya, barang yang ditransaksikan akan dikirim melalui jasa kurir logistik.

Pada setiap transaksi barang secara online membutuhkan dukungan dari jasa kurir logistik untuk mengirimkan barang. Perusahaan jasa kurir logistik di Indonesia yang besar dan melayani pengiriman antar kota dan antar provinsi diantaranya adalah: Tiki, JNE, J\&T, dan PT. Pos Indonesia.

Pemilihan kurir logistik untuk produk gadget yang memiliki harga mahal dan perlu penanganan hati-hati agar barang dapat selamat sampai ke konsumen memerlukan banyak kriteria. Kriteria yang banyak membutuhkan kekonsistenan jika dipakai untuk memilih suatu alternatif. Analytical Hierarchy Process(AHP) dan Analytic Network
Process (ANP) adalah salah satu metode yang banyak digunakan untuk menentukan bobot kriteria untuk memilih alternatif.

Pada penelitian terdahulu, Ligar dan Banowosari (2018) menggunakan metode AHP (Analytical Hierarchy Process) untuk membantu pengambilan keputusan memilih jasa kurir logistik (JNE, Tiki, dan PT. Pos Indonesia) pada $e$ commerce. Pada Penelitian ini akan dilakukan pemilihan jasa kurir logistik menggunakan metode Analytic Network Process (ANP) dan AHP serta membandingkan keduanya berkaitan dengan hasil alternatif yang dipilih serta pembobotan yang didapatkan.

\section{Tinjauan Pustaka}

II.1. Logistik

Logistik adalah bagian dari proses supply chain yang merencanakan, menerapkan dan mengendalikan efektivitas dan efisiensi aliran barang dan jasa serta informasi dari tempat titik awal atau asalnya menuju ke tempat tujuan agar memenuhi kebutuhan pelanggan (Councils of Logistics Management (1998) dalam Rafele (2004)).

\section{II.2. Layanan Logistik}

Dalam penerapan layanan logistik (logistics service), secara konvesional layanan logistik hanyalah berupa sekedar kegiatan yang mentransfer barang hasil produksi untuk dikonsumsi. Namun pada pertengahan tahun 1990-an, konsep ini berubah yaitu dengan adanya perusahaan jasa logistik yang diharapkan mampu menyediakan layanan 
berkualitas dan menghasilkan kepuasan pelanggan yang lebih besar dan juga menciptakan loyalitas pengguna layanan logistik (Mentzer et al., 2004; Richey et al., 2007 dalam Saura et al., 2008). Perusahaan logistik yang unggul atau excellent dikenali karena mampu menciptakan competitive advantage (Mentzer et al., 2001).

\section{II.3. Courier Service}

Pengertian kurir sebagaimana dinyatakan oleh The oxford dictionary (1954), "courier as an organization that provides a special delivery for parcels, documents etc." (dalam Somasundaram, Balasubramani, \& Krishnamoorthy, 2013, p. 108). Berdasarkan definisi tersebut, bisa dijelaskan bahwa layanan kurir adalah bisnis pengantaran barang atau dokumen yang dilakukan oleh perorangan maupun perusahaan.

\section{II.4. Analytic Network Process (ANP)}

Metode Analytic Network Process (ANP) merupakan pengembangan metode Analytical Hierarchy Process (AHP). Metode ANP mampu memperbaiki perbedaan struktur pada AHP berupa kemampuan mengakomodasi keterkaitan antar kriteria atau alternatif. Keterkaitan pada metode ANP ada dua jenis yaitu keterkaitan dalam satu set elemen (inner dependence) dan keterkaitan antar elemen yang berbeda (outerdependence). Adanya keterkaitan tersebut menyebabkan metode ANP lebih kompleks dibanding metode AHP (Saaty, 1998).

Tabel 1. Pedoman Pemberian Nilai dalam Perbandingan Berpasangan

\begin{tabular}{|c|c|c|}
\hline $\begin{array}{c}\text { Kepenti } \\
\text {-ngan }\end{array}$ & Definisi & Penjelasan \\
\hline 1 & $\begin{array}{l}\text { Kedua Kriteria } \\
\text { Sama Penting }\end{array}$ & $\begin{array}{l}\text { Kedua elemen memiliki } \\
\text { pengaruh yang sama }\end{array}$ \\
\hline 3 & $\begin{array}{l}\text { Kriteria yang satu } \\
\text { sedikit lebih } \\
\text { penting }\end{array}$ & $\begin{array}{l}\text { Pengalaman dan } \\
\text { penilaian sedikit lebih } \\
\text { memihak pada salah satu } \\
\text { elemen di banding } \\
\text { pasangannya }\end{array}$ \\
\hline 5 & $\begin{array}{l}\text { Kriteria yang satu } \\
\text { lebih penting dari } \\
\text { pada yang lainnya }\end{array}$ & $\begin{array}{l}\text { Pengalaman dan } \\
\text { penilaian dengan kuat } \\
\text { memihak satu elemen } \\
\text { dibandingkan } \\
\text { pasangannya }\end{array}$ \\
\hline 7 & $\begin{array}{l}\text { Kriteria yang satu } \\
\text { jelas sangat } \\
\text { penting dari pada } \\
\text { kriteria yang } \\
\text { lainnya }\end{array}$ & $\begin{array}{l}\text { Satu elemen sangat } \\
\text { disukai dan secara praktis } \\
\text { dominasinya terlihat }\end{array}$ \\
\hline 9 & $\begin{array}{l}\text { Kriteria yang satu } \\
\text { mutlak sangat } \\
\text { penting dari pada } \\
\text { kriteria yang } \\
\text { lainnya }\end{array}$ & $\begin{array}{l}\text { Satu elemen sangat } \\
\text { disukai dan secara praktis } \\
\text { dominasinya terlihat }\end{array}$ \\
\hline $2,4,6,8$ & $\begin{array}{l}\text { Nilai tengah } \\
\text { diantara dua } \\
\text { pertimbangan } \\
\text { yang berdekatan }\end{array}$ & $\begin{array}{l}\text { Ketika diperlukan sebuah } \\
\text { kompromi }\end{array}$ \\
\hline $\begin{array}{l}\text { Kebali- } \\
\text { kan }\end{array}$ & \multicolumn{2}{|l|}{$a_{i j}=1 / a_{i j}$} \\
\hline
\end{tabular}

Sumber: Saaty (1999)
Pembobotan dengan ANP membutuhkan model yang merepresentasikan saling keterkaitan antar kriteria dan subkriteria yang dimilikinya. Ada kontrol yang perlu diperhatikan didalam memodelkan sistem yang hendak diketahui bobotnya. Kontrol pertama adalah kontrol hirarki yang menunjukkan keterkaitan kriteria dan sub kriteria. Pada kontrol ini tidak membutuhkan struktur hirarki seperti pada metode AHP. Kontrol lainnya adalah kontrol keterkaitan yang menunjukkan adanya saling keterkaitan antar kriteria atau cluster (Saaty, 1999). Berikut ini adalah langkah-langkah pembuatan ANP menurut Saaty (1999):

Langkah 1: Konstruksi model dan strukturisasi masalah. Konstruksi model dibuat berdasarkan masalah yang ada, sehingga perlu dilakukan pendeskripsian masalah secara jelas, dan membentuknya ke dalam jaringan.

Langkah 2: Matriks perbandingan berpasangan yang menunjukkan keterkaitan.Perbandingan berpasangan pada ANP dilakukan dengan membandingkan tingkat kepentingan setiap elemen terhadap kriteria kontrolnya. Skala yang dipergunakan untuk perbandingan menurut Saaty (1999) dengan penilaian seperti pada Tabel 1.

Langkah 3: Perhitungan bobot elemen (Nilai Eigenvector).Setelah dilakukan matriks perbandingan berpasangan, selanjutnya menentukan nilai eigen dari matriks tersebut. Perhitungan eigenvector dengan cara menjumlahkan nilai setiap kolom dari matriks kemudian membagi setiap nilai sel kolom dengan total kolom dan menjumlahkan nilai-nilai dari setiap baris dan dibagi n. Nilai eigenvector dihitung dengan persamaan 1 .

$$
X_{i}=\frac{\sum_{j=1}^{n}\left(\frac{W i j}{\Sigma W j}\right)}{n}
$$

Keterangan:

$$
\begin{array}{ll}
X_{i} & \text { : eigenvector (bobot) baris } i \\
\mathrm{i} ; \mathrm{j} & \text { : baris; kolom } \\
\mathrm{W}_{\mathrm{ij}} & : \text { nilai dalam satu baris } \mathrm{i}(\mathrm{j}=1,2, \ldots \mathrm{n}) \\
\Sigma \mathrm{W}_{\mathrm{j}} & : \text { jumlah total kolom } \mathrm{j}(\mathrm{j}=1,2, \ldots \mathrm{n}) \\
\mathrm{n} & : \text { ukuran ordo matriks }
\end{array}
$$

Langkah 4: Perhitungan Rasio Konsistensi.Setelah mendapat nilai eigen, selanjutnya memeriksa rasio konsistensi, rasio konsistensi adalah rasio yang menyatakan apakah penilaian yang diberikan oleh para expertise konsisten/ tidak. Langkah pertama mencari nilai $\lambda \max$ menggunakan persamaan 2 .

$$
\lambda \max =\sum_{i, j=1}^{n}\left(\sum W_{j} * X_{i}\right) \ldots \ldots \ldots \ldots \ldots \ldots \ldots
$$

$$
\begin{aligned}
& \text { Keterangan: } \\
& W_{j} \quad \text { : jumlah total kolom } \mathrm{j}(\mathrm{j}=1,2, \ldots \mathrm{n}) \\
& X_{i} \quad \text { : eigenvector (bobot) baris } i
\end{aligned}
$$

Setelah mendapat lambda maksimum 
kemudian mencari Consistency Index atau Indeks konsistensi (CI) suatu matriks perbandingan dihitung dengan persamaan 3 :

$$
C I=\frac{\lambda \max -n}{n-1} \text {. }
$$

Rasio konsistensi (CR) diperoleh dengan menbandingkan indeks konsistensi dengan nilai dari bilangan indeks konsistensi acak (Random consistency index/RI) pada persamaan 4.

$$
C R=\frac{C I}{R I}
$$

\begin{tabular}{|c|c|}
\hline$\lambda \max$ & $\begin{array}{l}\text { : Nilai eigen terbesar dari matriks } \\
\text { perbandingan berpasangan } \mathrm{n} \times \mathrm{n}\end{array}$ \\
\hline$n$ & $\begin{array}{l}: \text { Jumlah item yang diperbandingkan } \\
\text { (ukuran matriks) }\end{array}$ \\
\hline$C I$ & : Indeks konsistensi/ Consistency Index \\
\hline$R I$ & : Random Index \\
\hline
\end{tabular}

Keterangan:

Tabel 2. Nilai Random Index

\begin{tabular}{|c|c|c|c|c|c|c|c|c|c|}
\hline $\mathrm{n}$ & 1 & 2 & 3 & 4 & 5 & 6 & 7 & 8 & 9 \\
\hline $\mathrm{RI}$ & 0 & 0 & 0,58 & 0,9 & 1,12 & 1,24 & 1,32 & 1,41 & 1,45 \\
\hline \multicolumn{10}{c|}{ Sumber: Saaty (1999) }
\end{tabular}

Langkah 5: Pembentukan super matriks. Supermatriks adalah matriks yang terdiri dari sub sub matriks yang disusun dari suatu set hubungan antara dua level yang terdapat dalam model. Terdapat tiga tahap supermatriks yang harus diselesaikan pada model ANP, yaitu:

\section{a. Unweighted supermatrix}

Setiap kolom dalam unweighted supermatrix berisi eigenvector yang berjumlah satu pada setiap clusternya, sehingga secara total, satu kolom akan memiliki penjumlahan eigenvector lebih dari 1.

b. Weighted supermatrix

Supermatriks ini diperoleh dengan mengalikan seluruh eigenvector dalam unweighted supermatrix dengan bobot clusternya masing-masing.

\section{c. Limit supermatrix}

Limit supermatrix berisi bobot prioritas global dalam weighted supermatrix yang telah konvergen dan stabil. Nilainya diperoleh melalui weighted supermatrix dipangkatkan dengan $2 \mathrm{k}+1$, dimana $\mathrm{k}$ adalah suatu bilangan yang besar.

Pemilihan Alternatif Terbaik.

Setelah memperoleh nilai setiap elemen pada limit matrix, langkah selanjutnya adalah melakukan perhitungan terhadap nilai elemen-elemen tersebut sesuai dengan model ANP yang dibuat. Alternatif dengan prioritas global tertinggi adalah alternatif yang terbaik.

\section{II.5. Analytical Hierarchy Process (AHP)}

AHP pertama kali dikembangkan oleh Thomas L. Saaty, seorang ahli matematika dari Universitas Pitssburg, Amerika Serikat pada tahun 1970-an. Analytical Hierarchy Process (AHP) pada dasarnya didesain untuk menangkap secara rasional persepsi orang yang berhubungan sangat erat dengan permasalahan tertentu melalui prosedur yang didesain untuk sampai pada suatu skala preferensi diantara berbagai set alternatif (Taylor, 2014). Konsep metode Analytical Hierarchy Process (AHP) sebenarnya adalah merubah nilai-nilai kualitatif menjadi nilai kuantitatif. Sehingga keputusan-keputusan yang diambil bisa lebih obyektif. Analytical Hierarchy Process (AHP) merupakan analisis yang digunakan dalam pengambilan keputusan dengan pendekatan sistem, dimana pengambil keputusan berusaha memahami suatu kondisi sistem dan membantu melakukan prediksi dalam mengambil keputusan dalam menyelesaikan persoalan dengan Analytical Hierarchy Process (AHP).

Perbedaan AHP dan ANP berawal dari aksioma ketiga tentang struktur hirarki yang tidak berlaku untuk ANP. Aksioma ini menyatakan bahwa judgements (penilaian), atau prioritas dari elemenelemen tidak tergantung pada elemen-elemen pada level yang lebih rendah. Aksioma ini mengharuskan penerapan struktur yang hirarkis. Perbedaan struktur kerangka model yang berbentuk hirarki pada AHP dan berbentuk jaringan pada ANP membuat ANP dapat diaplikasikan lebih luas dari AHP.

\section{Metode Penelitian}

Data yang digunakan pada penelitian ini adalah data primer yang berupa pendapat responden tentang tingkat kepentingan kriteria dan subkriteria yang dipakai untuk pembangkitan model pendukung keputusan dalam menentukan jasa pengiriman produk gadget. Pendapat responden tersebut diperoleh melalui penyebaran kuesioner. Responden dalam penelitian ini adalah pemilik toko, manajer, dan admin toko online dengan produk berupa gadget. Berdasarkan hasil wawancara dan penelitian terdahulu oleh Ligar dan Banowosari (2017), didapatkan 5 kriteria dan 19 subkriteria yang dipertimbangkan dalam penelitian ini.

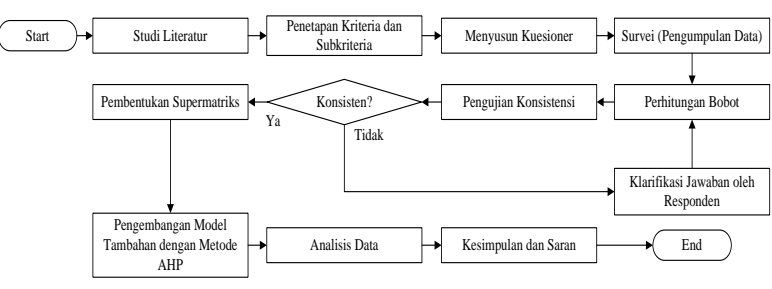

Gambar 1. Flowchart Prosedur Penelitian

Pada tahap pengolahan data, metode ANP diimplementasikan untuk menentukan bobot kepentingan pada kriteria, subkriteria dan alternatif. Pemeringkatan elemen dilakukan dengan matriks, kemudian dilakukan pengujian konsistensi untuk mengetahui konsistensi dari kuesioner yang telah diisi. Jika kuesioner yang diisi responden tidak konsisten, maka akan dilakukan klarifikasi jawaban ulang. Menurut Saaty nilai CR harus sama dengan atau kurang dari 0,1 dan jika tidak, maka perlu dilakukan revisi. Responden dalam penelitian ini berjumlah 5 orang, sehingga hasil kuesioner masing- 
masing responden harus digabungkan untuk mendapatkan hasil analisis gabungan dengan cara menggunakan rumus rata-rata geometrik. Jika semua sudah konsisten, hasil implementasi metode ANP ini kemudian akan dibentuk supermatriks untuk mendapatkan peringkat alternatif, yang kemudian akan dibandingkan hasil akhirnya dengan metode AHP.

\section{Hasil Penelitian dan Pembahasan}

\section{IV.1. Penetapan Kriteria dan Subkriteria}

Langkah pertama yang perlu dilakukan adalah mendefinisikan masalah. Masalah pada penelitian ini adalah bagaimana memilih jasa pengiriman yang terbaik bagi penjual gadget online. Langkah kedua adalah menentukan kriteria mana yang dianggap penting oleh penjual gadget, untuk kriteria, subkriteria, dan alternatif didapatkan dari penelitian terdahulu oleh Ligar dan Banowosari (2017) pada pemilihan jasa pengiriman produk pada e-commerce yang kemudian dilakukan reduksi dan penambahan variabel, maka didapatkan sebanyak 5 kriteria yang didalamnya terdapat 19 subkriteria. Kuesioner disebar kepada 5 responden, responden yang dipilih adalah pemilik bisnis online yang menjual gadget dengan menggunakan jasa pengiriman kurir logistik di Kota Surabaya.

Tabel 3. Kriteria dan Subkriteria Terpilih

\begin{tabular}{|l|l|}
\hline \multicolumn{1}{|c|}{ Kriteria } & \multicolumn{1}{c|}{ Subkriteria } \\
\hline \multirow{4}{*}{ Keandalan Pengiriman } & Keamanan Pengiriman \\
\cline { 2 - 2 } & Ketepatan Tujuan \\
\cline { 2 - 2 } & Ketepatan Waktu \\
\cline { 2 - 2 } Fitur Layanan & Kondisi Kemasan \\
\hline \multirow{5}{*}{ Harga } & Pelacakan Kiriman \\
\cline { 2 - 2 } & Tujuan Pengiriman Luas \\
\cline { 2 - 2 } & Layanan Beragam \& Lengkap \\
\cline { 2 - 2 } Kompetensi Pegawainan Ganti Rugi \\
\cline { 2 - 2 } & Layanan Cashless \\
\cline { 2 - 2 } & Membership \\
\hline \multirow{4}{*}{ Citra Perusahaan } & Harga Lebih Murah \\
\cline { 2 - 2 } & Diskon \\
\hline & Keramahan \\
\cline { 2 - 2 } & Daya Tanggap \\
\cline { 2 - 2 } & Kecakapan \\
\hline \multirow{4}{*}{ Kanajemen dan Operasional } \\
\cline { 2 - 2 } & Jumlah Agen Banyak \\
\cline { 2 - 2 } & Promosi di Media Publik \\
\cline { 2 - 2 } & Kemudahan Akses \\
\hline
\end{tabular}

\section{IV.2. Uji Rasio Konsistensi}

Langkah ketiga yaitu membuat matriks perbandingan berpasangan kriteria, subkriteria dan alternatif, kemudian langkah keempat dilakukan uji konsistensi rasio. Berdasarkan hasil pengecekan, semua matriks perbandingan memiliki rasio inkonsistensi kurang dari 0,1. Hal ini berarti pengisian kuesioner sudah konsisten. Uji sintesis yang digunakan dalam metode ANP adalah meliputi perhitungan geometric mean. Rata-rata geometrik digunakan karena nilai yang diberikan responden bersifat perbandingan, sehingga lebih cocok digunakan dibanding rata-rata aritmatik. Langkah kelima seluruh nilai data perbandingan dimasukkan, maka diperoleh unweighted supermatrix, weighted supermatrix, dan limit supermatrix. Hasil prioritas tiap subkriteria berdasarkan hasil limit matrix. Berikut adalah bobot kriteria dan subkriteria yang terdapat pada Tabel 4:

Tabel 4. Bobot Kriteria Dalam Pemilihan Jasa Kurir (ANP)

\begin{tabular}{|l|c|c|}
\hline \multicolumn{1}{|c|}{ Kriteria } & Nilai Eigen & Rank \\
\hline Keandalan Pengiriman & 0,452524743 & 1 \\
\hline Fitur Layanan & 0,298123847 & 2 \\
\hline Citra Perusahaan & 0,117816286 & 3 \\
\hline Kompetensi Pegawai & 0,080397914 & 4 \\
\hline Harga & 0,05113721 & 5 \\
\hline
\end{tabular}

Berdasarkan Tabel 4, elemen kriteria yang memiliki tingkat kepentingan paling tinggi adalah Keandalan Pengiriman, Fitur Layanan, Citra Perusahaan, Kompetensi Pegawai, kemudian Harga.

Berdasarkan Tabel 5, elemen subkriteria yang memiliki tingkat kepentingan paling tinggi adalah Ketepatan Waktu, Jaminan Ganti Rugi, Pelacakan Kiriman, dan urutan keempat sampai kesembilan belas bobotnya dibawah $10 \%$.

Tabel 5. Bobot Subkriteria Dalam Pemilihan Jasa Kurir (ANP)

\begin{tabular}{|l|c|c|}
\hline \multicolumn{1}{|c|}{ Subkriteria } & $\begin{array}{c}\text { Nilai } \\
\text { Eigen } \\
\text { Global }\end{array}$ & $\begin{array}{c}\text { Rank } \\
\text { Global }\end{array}$ \\
\hline Ketepatan Waktu & 0,209624 & 1 \\
\hline Jaminan Ganti Rugi & 0,143339 & 2 \\
\hline Pelacakan Kiriman & 0,104241 & 3 \\
\hline Layanan Beragam \& Lengkap & 0,076407 & 4 \\
\hline Keamanan Pengiriman & 0,07511 & 5 \\
\hline .. & 0,066441 & 6 \\
\hline Membership & 0,00907 & 19 \\
\hline
\end{tabular}

\section{IV.3. Hasil Alternatif ANP}

Tabel 6. Hasil Bobot Penilaian Alternatif (ANP)

\begin{tabular}{|c|c|c|c|}
\hline \multirow{2}{*}{ Alternatif } & & $\%$ & Rank \\
\hline JNE & 0,330963 & $33,10 \%$ & 1 \\
\hline J\&T & 0,232193 & $23,22 \%$ & 3 \\
\hline TIKI & 0,251522 & $25,15 \%$ & 2 \\
\hline POS & 0,185321 & $18,53 \%$ & 4 \\
\hline
\end{tabular}

Pada Tabel 6, di dapat hasil perankingan alternatif terbaik dengan menggunakan metode ANP. Dari penilaian tersebut dapat diketahui bahwa JNE merupakan jasa kurir terbaik menurut pebisnis gadget online di Surabaya.

\section{IV.4. Metode AHP (Analytical Hierarchy Process)}

Pada tahap ini dilakukan pertimbangan tambahan untuk membandingkan hasil bobot perhitungan jasa kurir terbaik dari metode ANP dengan metode AHP.

Tabel 7. Bobot Kriteria Dalam Pemilihan Jasa Kurir (AHP)

\begin{tabular}{|l|c|c|}
\hline \multicolumn{1}{|c|}{ Bobot Kriteria } & & Rank \\
\hline Keandalan Pengiriman & 0,417875753 & 1 \\
\hline Fitur Layanan & 0,268276395 & 2 \\
\hline Citra Perusahaan & 0,138166672 & 3 \\
\hline Kompetensi Peg awai & 0,095329283 & 4 \\
\hline Harga & 0,080351897 & 5 \\
\hline
\end{tabular}


Berdasarkan Tabel 7, elemen kriteria yang memiliki tingkat kepentingan paling tinggi adalah Keandalan Pengiriman, Fitur Layanan, Citra Perusahaan, Kompetensi Pegawai, kemudian Harga, urutannya sama seperti metode ANP.

Tabel 8. Bobot Subkriteria Dalam Pemilihan Jasa Kurir (AHP)

\begin{tabular}{|l|c|c|}
\hline \multicolumn{1}{|c|}{ Subkriteria } & $\begin{array}{c}\text { Nilai Eigen } \\
\text { Global }\end{array}$ & $\begin{array}{c}\text { Rank } \\
\text { Global }\end{array}$ \\
\hline Ketepatan Waktu & 0,199925056 & 1 \\
\hline Jaminan Ganti Rugi & 0,105125903 & 2 \\
\hline Keamanan Pengiriman & 0,082567671 & 3 \\
\hline Kondisi Kemasan & 0,078880963 & 4 \\
\hline Kemudahan Akses & 0,065487591 & 5 \\
\hline ... & $\ldots$ & $\ldots$ \\
\hline Promosi di Media Publik & 0,012227991 & 19 \\
\hline
\end{tabular}

Berdasarkan Tabel 8, elemen subkriteria yang memiliki tingkat kepentingan paling tinggi adalah Ketepatan Waktu, Jaminan Ganti Rugi, dan urutan ketiga sampai kesembilan belas bobotnya dibawah $10 \%$.

\section{IV.5. Hasil Alternatif AHP}

Tabel 9. Hasil Bobot Penilaian Alternatif (AHP)

\begin{tabular}{|c|c|c|c|}
\hline Alternatif & & \% & Rank \\
\hline JNE & 0,329751917 & $32,98 \%$ & 1 \\
\hline J\&T & 0,222897746 & $22,29 \%$ & 3 \\
\hline TIKI & 0,25462356 & $25,46 \%$ & 2 \\
\hline POS & 0,192726776 & $19,27 \%$ & 4 \\
\hline
\end{tabular}

Pada Tabel 9, di dapat hasil perankingan alternatif terbaik dengan menggunakan metode AHP. Dari penilaian tersebut dapat diketahui bahwa JNE merupakan jasa kurir terbaik menurut pebisnis gadget online di Surabaya.

\section{IV.6. Struktur Hirarki dan Jaringan}

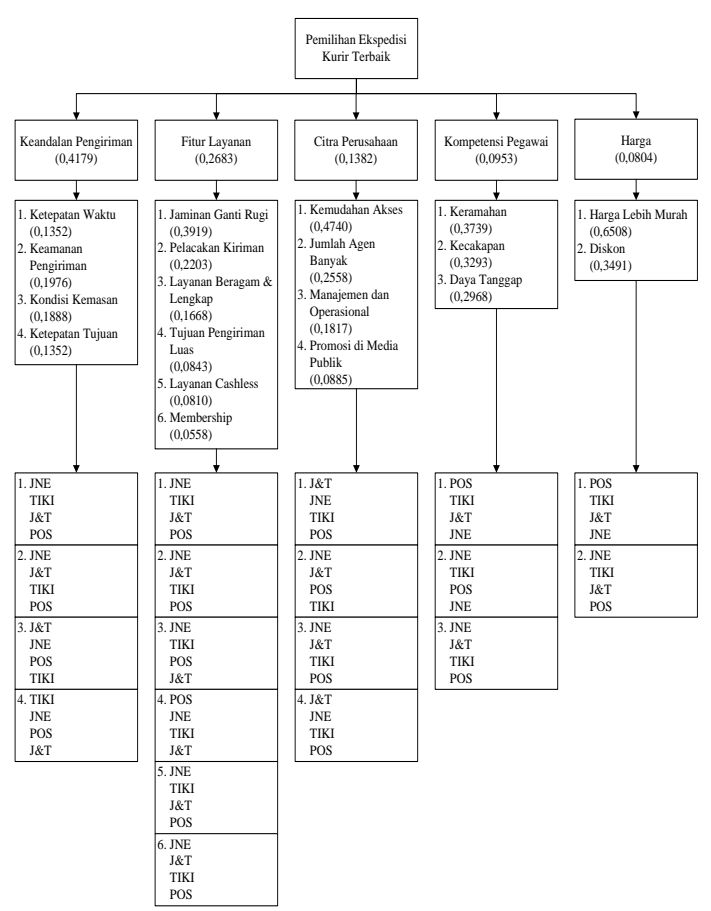

Gambar 2. Struktur Hirarki Pemilihan Jasa Kurir (AHP)
Dalam lingkungan e-commerce, salah satu faktor terpenting adalah ketepatan waktu pengiriman, karena jika paket datang dengan aman dan tepat waktu, kemungkinan besar pelanggan akan sering menggunakan jasa kurir tersebut. Kemudian faktor lainnya yang juga tidak kalah penting adalah tersedianya jaminan ganti rugi bagi penjual, karena jika gadget mengalami kerusakan saat pengiriman, maka barang dari pembeliakan dikembalikan ke penjual gadget, ini menggambarkan bahwa penjual gadget butuh jaminan atau rasa aman ketika menggunakan layanan jasa pengiriman. Perusahaan yang tidak bisa beradaptasi dengan preferensi pelanggan dapat menjadikannya tidak dapat bersaing dengan perusahaan yang lebih berfokus pada peningkatan ketepatan waktu pengiriman dan rasa aman pelanggan.

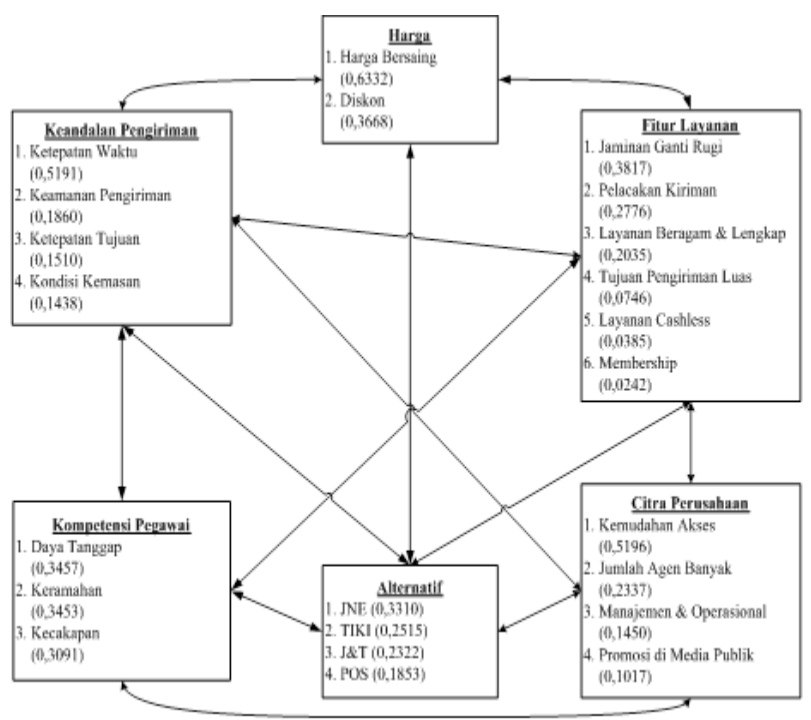

Gambar 3. Struktur Jaringan Pemilihan Jasa Kurir (ANP)

Dalam lingkungan $e$-commerce, salah satu faktor terpenting adalah ketepatan waktu pengiriman, karena jika paket datang dengan aman dan tepat waktu, kemungkinan besar pelanggan akan sering menggunakan jasa kurir tersebut. Kemudian faktor lainnya yang juga tidak kalah penting adalah tersedianya jaminan ganti rugi bagi penjual, karena jika gadget mengalami kerusakan saat pengiriman, maka barang dari pembeliakan dikembalikan ke penjual gadget, ini menggambarkan bahwa penjual gadget butuh jaminan atau rasa aman ketika menggunakan layanan jasa pengiriman. Perusahaan yang tidak bisa beradaptasi dengan preferensi pelanggan dapat menjadikannya tidak dapat bersaing dengan perusahaan yang lebih berfokus pada peningkatan ketepatan waktu pengiriman dan rasa aman pelanggan.

\section{Kesimpulan}

Berdasarkan hasil pengolahan data dan analisis didapatkan bahwa terdapat sedikit perbedaaan dalam 
nilai bobot kriteria antara metode ANP dan AHP. Akan tetapi urutan perolehan skor untuk tiap alternatif tidak mengalami perbedaan antara menggunakan metode ANP dan Metode AHP.

\section{Daftar Pustaka}

1. Azis, I., J. (2003). Analytic Process With Feedback Influence: A New Approach to Impact Study. University of Illinois.

2. Bernadus, Ricky. (2018). Pemilihan vendor pengiriman barang di PT. Energy Logistics Manado dengan menggunakan metode Analytical Network Process. Universitas Katolik Parahyangan.

3. Ekawati, R., Trenggonowati, D. L., Aditya, V. D. (2018). Penilaian Performa Supplier Menggunakan Pendekatan Analytic Network Process. Journal Industrial Services Vol. 3, No.2.

4. Hajar, D., Arifin, S. P. (2015). Analisis Pengambilan Keputusan Pemilihan Perusahaan Penyedia 3PL di Pekanbaru. Jurnal Komputer Terapan, Vol 1, No.2, pp. 85-94.

5. Indrajit, Ricardus. (2001). E-commerce Kiat dan Strategi di Dunia Maya. Jakarta: PT. Elex Media Komputerindo.

6. Kaluku, M. R., Pakaya Nikmasari. (2017). Penerapan Perbandingan Metode AHP-TOPSIS dan ANP-TOPSIS Mengukur Kinerja Sumber Daya Manusia di Gorontalo. ILKOM Jurnal Ilmiah Vol 9. No. 2.

7. Koleangan. (2004). Sistem Petikemas. STMT Trisakti, Jakarta.

8. Ligar, B., Banowosari, L. Y. (2017). Pemilihan Jasa Pengiriman Produk Pada E-Commerce Menggunakan Analytical Hierarchy Process (AHP). UG Jurnal vol. 11, No. 8

9. Mentzer, J.T., Flint, D.J, and Hult, G.T.M. (2001). Logistic service quality asa segmentcustomized process. Journal of marketing, 65(4), pp.82-104.

10. Prasetyo, F.A. (2017). Analisis Perbandingan Service Quality antara JNE dan J\&T Ekspress. Jurnal Strategi Pemasaran vol 4, No.2.

11. Rafele, C. (2004). Logistic service measurement: a reference framework. Journal of Manufacturing Technology Management, 15(3), pp.280-290.

12. Rinawati, D., Handoko, M. (2015). Integrasi Metode Analytical Network Process dan Technique For Others Preference By Similarity to Ideal Solution (TOPSIS) dalam Menentukan Prioritas Supplier Bahan Baku (Studi kasus PT. Nyoya Meneer Semarang). Jurnal Teknik Industri, vol. 10, no. 1, pp.7-18.

13. Saaty, T. L. (1994). The Fundamentals of Decision Making and Priority Theory With the Analytic Hierachy Process, RWS Publication, Pittsburgh.

14. Saaty, T. L. (1998). Multicriteria Decision Making The Analytic Hierarchy Process. United States of America.

15. Saaty, T. L. (1999). Fundamental of Decision making: The Analytic Hierarchy Process..
Pittsburgh: RWS Publication, 4922 Ellsworth Ave.

16. Saaty, T. L. (1999). Fundamental of the analytic network process. Pittsburgh: ISAHP, Kobe.

17. Saaty, T. L. (2001). Decision Making with Dependence and Feedback: The Analytic Network Process (second ed.). Pittsburg, USA: RWS Publication, 4922 Ellsworth Ave.

18. Saaty, T. L. (2004). Fundamental of the analytic network process and feedback in decisionmaking with a single network. Pittsburgh: RWS Publication.

19. Sabatini L.N., Ardiana I. M., Praseyta O. (2017). Loyalitas Pelanggan Pada Perusahaan Freight Forwarding. Jurnal Manajemen Transportasi \& Logistik 3, pp.299-308

20. Sarkis, J. (2003). A Strategic Decisioon Framework for Green Supply Chain Management Literatur. Eluivire Ltd.

21. Saura, I. G., Frances, D. S., Contri, G. B., dan Blanco, M. F. (2008). Logistics Service Quality: A New Way to Loyalty. Industrial Management and Data Systems, Vol. 108 (5), pp. 650-668

22. Shin S.Y., Pak M.S. (2016). The Critical Factors for Korea Freight Forwarder Purchasing Negotiation in International Logistics. Asian Journal of Shipping and Logistics 32(4):195-201

23. Somasundaram B., Krishnamorrty. (2013). Customer Behaviour of Courier Service in Erode District. Indian Journal of Research 2(1).

24. Steven, M. L. (2014). Discrete choice Model for Air-Cargo Mode Selection. The International Journal of Logistics Management 25(3):656-672.

25. Tjiptono, Fandy \& Chandra, Gregorius. (2011). Service, quality \& satisfaction. (3rd ed). Yogyakarta: Andi Offset

26. Vinsensia, Desi. (2014). Analisis Kepuasan Konsumen Terhadap Pelayanan Pelayanan Jasa Pengiriman Paket (Kurir) Dengan Menggunakan Metode Topsis Fuzzy. Jurnal Pelita Nusantara Vol. 16, No.2.

27. Wiwoho, Adhi. (2014). Pemilihan Supplier Menggunakan Metode Analytic Network Process di PT. Harvita Tisi Mulia Semarang. Universitas Dian Nuswantoro.

28. Wulan A., Hendrawan B. (2018). Analisis Pemilihan Jasa Forwarder dengan Menggunakan Metode AHP di PT.XYZ. Journal of Applied Business Administration.

29. Wulandari P. F., Arvianto, A. (2016). Pemilihan Jasa Ekspedisi Dengan Menggunakan Metode Analytical Hierarchy Process. Universitas Diponegoro.

30. Yamit, Z. (2013). Manajemen Kualitas Produk \& Jasa. Yogyakarta: Ekonisia

31.Yurdakul, M. (2002). Measurung a Manufacturing System Perfomance Using Saaty's System with feedback approach. Integrated Manufacturing System, Vol.13. 